\title{
ANALISIS KEMAMPUAN PEMECAHAN MASALAH MATEMATIS SISWA SMP PADA MATERI SEGIEMPAT DAN SEGITIGA
}

\author{
Puri Nur Aisyah $^{1}$, Siti Umi Nur Khasanah ${ }^{2}$, Anik Yuliani $^{3}$, Euis Eti Rohaeti ${ }^{4}$ \\ ${ }^{1,2,3,}$ Pendidikan Matematika, IKIP Siliwangi \\ Jl. Terusan Jendral Sudirman Cimahi 40526 \\ 1Email: purinura47@gmail.com,_umi94@gmail.com,_[3nik_yuliani04070886@ikipsiliwangi.ac.id, \\ ${ }^{4} \mathrm{e} 2 \mathrm{rht} @$ yahoo.com
}

\begin{abstract}
This study aims to determine the ability of solving mathematical problems of junior high school students in Kabupatan West Bandung with indicators of students' mathematical problem solving abilities that are used to identify known elements, questioned and adequacy of elements, selecting and implementing strategies to solve mathematical problems, interpret the results according to the initial problem , making a mathematical model of a situation or everyday problem, using mathematics meaningfully. This research was conducted to 31 students in one of Junior High School in Ngamprah Village, West Bandung Regency using qualitative descriptive method. Instruments used in the form of 5 items about students' mathematical problem solving abilities on the material quadrilateral and triangle with interviews to students. The conclusion of this research is the ability of mathematical problem solving of junior high school students in Ngamprah Village is still low.
\end{abstract}

Keywords: Mathematical problem solving ability,Quadrilateral and triangle.

\begin{abstract}
Abstrak
Penelitian ini bertujuan untuk mengetahui kemampuan pemecahan masalah matematis siswa SMP di Kabupatan Bandung Barat dengan indikator kemampuan pemecahan masalah matematis siswa yang digunakan adalah mengidentifikasi unsur yang diketahui, ditanyakan dan kecukupan unsur, memilih dan menerapkan strategi untuk menyelesaikan masalah matematika, menginterpretasi hasil sesuai dengan permasalahan awal, membuat model matematik dari suatu situasi atau masalah sehari-hari, menggunakan matematika secara bermakna. Penelitian ini dilakukan kepada 31 siswa di salah satu SMP di Desa Ngamprah Kabupaten Bandung Barat dengan menggunakan metode deskriptif kualitatif. Instrumen yang digunakan berupa 5 butir soal kemampuan pemecahan masalah matematis siswa pada materi segiempat dan segitiga disertai wawancara kepada siswa. Kesimpulan dari penelitian ini adalah kemampuan pemecahan masalah matematis siswa SMPdi Desa Ngamprahmasih rendah.
\end{abstract}

Kata kunci: Kemampuan pemecahan masalah matematis,Segiempat dan segitiga

How to cite: Aisyah, P. N., Khasanah, S.U.N., Yuliani, A., \& Rohaeti, E. E. (2018). Analisis Kemampuan Pemecahan Masalah Matematis Siswa SMP pada Materi Segiempat dan Segitiga. JPMI - Jurnal Pembelajaran Matematika Inovatif, 1 (5), 1025-1036. 


\section{PENDAHULUAN}

Pendidikan merupakan upaya untuk membentuk sumber daya manusia yang dapat meningkatkan kualitas kehidupan. Oleh karena itu maka peningkatan mutu pendidikan merupakan hal yang wajib dilakukan secara berkesinambungan. Dalam proses pembelajaran ilmu pengetahuan, matematika merupakan salah satu ilmu yang memegang peranan penting terhadap perkembangan ilmu pengetahuan yang lain. Matematika dianggap sebagai ratu atau induknya ilmu yakni sumber dari ilmu yang lain. Dengan kata lain, banyak ilmu yang penemuan dan pengembangannya bergantung dari matematika.

Melihat betapa pentingnya peran matematika dalam kehidupan manusia, wajar jika matematika dianggap sebagai ilmu dasar yang harus dikuasai oleh manusia, terutama siswa. Di Indonesia, matematika dianggap sebagai mata pelajaran yang penting untuk dipelajari, hal ini terbukti dengan adanya mata pelajaran matematika pada setiap jenjang pendidikan baik pendidikan dasar maupun pendidikan menengah.

Menurut National Council of Teacher Mathematics atau NCTM (2000) terdapat lima kompetensi dalam pembelajaran matematika, yaitu: pemecahan masalah matematis (mathematical problem solving), komunikasi matematis (mathematical communication), penalaran matematis (mathematical reasoning), koneksi matematis (mathematical connection), dan representasi matematis (mathematical representation). Kelima kompetensi tersebut sangat diperlukan untuk kehidupan siswa sehingga menjadi warga Negara yang kreatif dan bermanfaat sesuai dengan tujuan pendidikan nasional. Tujuan tersebut terdapat dalam Pasal 3 Undang-undang No.20 Tahun 2003 yaitu untuk mengembangkan potensi peserta didik agar menjadi manusia yang beriman dan bertakwa kepada Tuhan Yang Maha Esa, berakhlak mulia, sehat, kreatif, mandiri dan menjadi warga Negara yang demokratis serta bertanggung jawab.

Berdasarkan penjelasan di atas, salah satu kemampuan yang harus dimiliki oleh siswa saat ini, yaitu kemampuan pemecahan masalah. Seperti yang diungkapkan NCTM (Apriyani, 2010)bahwa pemecahan masalah merupakan fokus dari pembelajaran matematika, karena pemecahan masalah merupakan sarana mempelajari ide dan keterampilan matematika. Kemampuan pemecahan masalah tidak saja menuntut siswa untuk menyelesaikan masalah dengan cara biasa sesuai dengan rumus yang ada, tapi lebih pada kemampuan untuk melakukan penyederhanaan, modelling, menemukan konsep melalui pemodelan dan menggunakan konsep untuk menyelesaikan masalah yang lebih kompleks.Hal ini sejalan dengan pendapat Hendriana, H., Sumarmo, U (2014) yang menyatakan bahwa pemecahan masalah matematika merupakan salah satu kemampuan dasar matematik yang harus dikuasai siswa sekolah menengah. Selain itu Hidayat dan Sariningsih (2018) mengemukakan bahwa dalam pembelajaran matematika pemecahan masalah merupakan inti pembelajaran yang menjadi kemampuan dasar dalam proses pembelajaran.

Namun kesadaran akan pentingnya kemampuan pemecahan masalah matematis dalam kehidupan sehari-hari belum disadari dengan baik. Berdasarkan temuan Putra (Putra, D, H., Thahiram, N, F., Ganiati, M., Nuryana, D, 2018)pada salah satu sekolah menengah di Bandung Barat dari 35 siswa dalam satu kelas hanya 14,29\% siswa yang sudah berada pada tahap berpikir formal (abstrak). Selain itu seperti yang diperoleh dari hasil observasi yang

dilakukan peneliti pada siswa SMP. Peneliti mendapati bahwa proses pembelajaran matematika di kelas cenderung pada pencapaian target materi kurikulum, lebih mementingkan pada penghafalan rumus bukan pemahaman. Kegiatan pembelajaran matematika di kelas kurang menekankan pada aspek kemampuan siswa dalam menemukan konsep-konsep dan 
struktur-struktur matematika berdasarkan pengalaman sendiri. Oleh karena pembelajaran seperti itulah siswa menjadi tidak menyukai matematika. Hal ini sejalan dengan Nurianti, Halini, \& Ijudin(Putra, D, H., Thahiram, N, F., Ganiati, M., Nuryana, D, 2018)bahwa siswa cenderung menghafal rumus tanpa memahami konsep dan mengerjakan masalah matematika dengan ceroboh. Secara teoritis sikap siswa terhadap matematika dapat mempengaruhi prestasi belajar matematika dan juga tentunya akan mempengaruhi kemampuan pemecahan masalah matematis siswa. Maka dari itu kemampuan pemecahan masalah sangat penting dikembangkan pada siswa SMP, karena pada jenjang Sekolah Menengah Pertama ini siswa mulai ditekankan pada daya berpikir tingkat tinggi.

Ruseffendi (2006) mengemukakan beberapa alasan mengapa siswa perlu dilatih menyelesaikan persoalan yang berupa pemecahan masalah. Beberapa alasan tersebut adalah :

1. Dapat menimbulkan keingintahuan dan adanya motivasi, menumbuhkan sifat kreatif;

2. Disamping memiliki pengetahuan dan keterampilan (berhitung dan lain-lain), disyaratkan adanya kemampuan untuk terampil membaca dan membuat pernyataan yang benar;

3. Dapat menimbulkan jawaban yang asli, baru, khas, beraneka ragam, dan dapat menambah pengetahuan baru;

4. Dapat meningkatkan aplikasi dari ilmu pengetahuan yang sudah diperolehnya;

5. Mengajak siswa memiliki prosedur penyelesain masalah, mampu membuat analisis, sintesis, dan dituntut untuk membuat evaluasi terhadap hasil pemecahannya;

6. Merupakan kegiatan yang penting bagi siswa, bukan saja melibatkan satu bidang studi, melainkan (bila diperlukan) banyak bidang studi, dapat melibatkan pelajaran lain diluar pelajaran sekolah, dapat merangsang siswa untuk menggunakan segala kemampuannya. Ini penting bagi siswa untuk menghadapi kehidupannya kini dan dikemudia hari.

Menurut Turmudi(Muhsin, Johar, R., Nurlaelah, E, 2013)mengungkapkan bahwa "problem solving atau pemecahan masalah dalam matematika melibatkan metode dan cara penyelesaian yang tidak standar dan tidak diketahui terlebih dahulu. Untuk mencari penyelesaian para siswa harus memanfaatkan pengetahuannya, dan melalui proses ini mereka akan sering mengembangkan pemahaman matematika yang baru".

Nasution (Kesumawati, 2009)menyatakanpenyelesaian masalah dapat dipandang sebagai proses di mana siswa menemukan kombinasi aturan-aturan yang telah dipelajarinya terlebih dahulu yang digunakannya untuk menyelesaikan masalah yang baru. Siswa yang terlatih dengan pemecahan masalah akan terampil menyeleksi informasi yang relevan, kemudian menganalisisnya dan akhirnya meneliti hasilnya. Keterampilan itu akan menimbulkan kepuasan intelektual dalam diri siswa, meningkatkan potensi intelektual, dan melatih siswa bagaimana melakukan penelusuran melalui penemuan. Ini berarti kemampuan pemecahan masalah merupakan hal yang harus mendapat perhatian, mengingat peranannya yang sangat strategis dalam mengembangkan potensial intelektual anak.

Berdasarkan paparan di atas, maka dapat peneliti simpulkan bahwa kemampuan pemecahan masalah adalah kemampuan menciptakan gagasan-gagasan atau cara-cara baru berkenaan dalam menyelesaikan suatu permasalahan dengan mengutamakan prosedur, strategi dan langkah-langkah yang tepat sehingga menemukan jawaban benar. 
Polya (Hendriana, H., Rohaeti, E, E., Sumarmo, U, 2017)mengartikan pemecahan masalah sebagai satu usaha mencari jalan keluar dari satu kesulitan guna mencapai satu tujuan yang tidak begitu mudah segera untuk dicapai.Polya (Suherman, 2003)mengungkapkan empat langkah yang harus dilakukan dalam pemecahan masalah, yaitu :

1. Memahami Masalah (understand the problem)

2. Membuat Rencana Pemecahan Masalah (devise a plan)

3. Menyelesaikan Rencana (carry out the plan)

4. Memeriksa Kembali Hasil yang Diperoleh (looking back)

Sedangkan menurut Sumarmo (Muhsin, Johar, R., Nurlaelah, E, 2013)untuk mengukur kemampuan pemecahan masalah matematis diperlukan beberapa indikator, yaitu:

1. Mengidentifikasi unsur yang diketahui, ditanyakan dan kecukupan unsur

2. Membuat model matematika

3. Menerapkan strategi menyelesaikan masalah dalam/diluar matematika

4. Menjelaskan atau mengiterpretasi hasil permasalahan awal

5. Menyelesaikan model matematika dan masalah nyata

6. Menggunakan matematika secara bermakna

Berdasarkan paparan di atas, maka peneliti mengambil indikator pemecahan masalah tersebut adalah 1) Mengidentifikasi unsur yang diketahui, ditanyakan dan kecukupan unsur; 2) Memilih dan Menerapkan strategi untuk menyelesaikan masalah matematika; 3) Menginterpretasi hasil sesuai dengan permasalahan awal; 4) Membuat model matematik dari suatu situasi atau masalah sehari-hari; 5) Menggunakan matematika secara bermakna.

\section{METODE}

Penelitian ini merupakan penelitian kualitatif. Subjek dalam penelitian ini adalah 31 orang. Siswa kelas VII di salah satu SMP negeri di Desa Ngamprah Kabupaten Bandung Barat. Waktu penelitian ini diadakan pada semester genap tahun ajaran 2017-2018. Teknik pengumpulan data dalam penelitian ini menggunakan instrumen tes kemampuan pemecahan masalah matematis. Teknik pengambilan sampel yaitu dengan teknik purposive sampling, dimana sampel dipilih sesuai kriteria yang telah dipilih oleh peneliti dengan kemampuan yang sama.Berdasarkan pertimbangan tersebut maka, ditentukan 6 orang subjek penelitian. Selain itu juga dilakukan wawancara terhadap subjek setelah tes berlangsung. Instrumen yang digunakan berupa soal uraian tes kemampuan pemecahan masalah matematis sebanyak 5 soal.Selain itu dihitung juga skor maksimal siswa dan persentasenya untuk mengetahui tingkat kemampuan pemecahan masalah matematis siswa dalam menyelesaikan soal tes kemampuan pemecahan masalah pada materi segiempat dan segitiga. Dalam perhitungan persentase skor akan dikualifikasikan menjadi lima kategori yaitu, sangat tinggi, tinggi, sedang, rendah dan sangat rendah berdasarkanSyah (1999) sebagai berikut:

Tabel 1.Kategori Persentase Pencapaian Kemampuan Pemecahan Masalah

\begin{tabular}{cc}
\hline Tingkat Penguasaan & Kriteria \\
\hline $\mathbf{8 1} \%-\mathbf{1 0 0} \%$ & Sangat Tinggi \\
$\mathbf{6 1} \%-\mathbf{8 0} \%$ & Tinggi \\
$\mathbf{4 1} \%-\mathbf{6 0} \%$ & Sedang \\
$\mathbf{2 1} \%-\mathbf{4 0} \%$ & Rendah \\
$\mathbf{0} \%-\mathbf{2 0} \%$ & Sangat Rendah \\
\hline
\end{tabular}




\section{HASIL DAN PEBAHASAN}

Hasil

Penelitian ini dilaksanakan pada salah satu kelas VII di SMP negeri di Desa Ngamprah Kabupaten Bandung Barat. Data hasil penelitian ini yaitu berupa hasil belajar siswa yang pengumpulan datanya menggunakan instrumen soal tess berupa uraian sebanyak 5 soal. Data tes diperoleh dari analisis jawaban siswa berdasarkan acuan pedoman penskoran kemampuan pemecahan masalah matematis. Mendeskripsikan kemampuan pemecahan masalah matematis siswa dalam menyelesaikan soal pada materi segiempat dan segitiga pada tiap soal ini meliputi setiap indikator.

Tabel 2. Deskripsi indikator Mengidentifikasi unsur yang diketahui, ditanyakan dan kecukupan unsur

\begin{tabular}{cc}
\hline Kode Siswa & Jumlah Skor \\
\hline 001 & 4 \\
002 & 4 \\
003 & 4 \\
004 & 4 \\
005 & 2 \\
006 & 4 \\
Jumlah & 21 \\
\hline Persentase (\%) & $87,5 \%$ \\
\hline
\end{tabular}

Berdasarkan tabel 2 tersebut menujukan kemampuan mengidentifikasi unsur yang diketahui, ditanyakan dan kecukupan unsur pada soal nomor 1 diperoleh persentase $61,11 \%$.

Tabel 3. Deskrpisi indikator Memilih dan Menerapkan strategi untuk menyelesaikan masalah matematika

\begin{tabular}{cc}
\hline Kode Siswa & Jumlah Skor \\
\hline 001 & 2 \\
002 & 2 \\
003 & 3 \\
004 & 1 \\
005 & 2 \\
006 & 4 \\
Jumlah & 14 \\
\hline Persentase (\%) & $58,33 \%$ \\
\hline
\end{tabular}

Berdasarkan tabel 3 tersebut menunjukan kemampuan memilih dan menerapkan strategi untuk menyelesaikan masalah matematika memperoleh persentase sebesar 58,33\%.

Tabel 4. Dekripsi indikatorMenggunakan matematika secara bermakna

\begin{tabular}{cc}
\hline Kode Siswa & Jumlah Skor \\
\hline 001 & 1 \\
002 & 3 \\
003 & 4 \\
004 & 3 \\
005 & 2 \\
006 & 3 \\
Jumlah & 16 \\
\hline Persentase $(\%)$ & $66,67 \%$ \\
\hline
\end{tabular}


Berdasarkan tabel 4 tersebut menunjukan kemampuan Menggunakan matematika secara bermaknamemperoleh persentase sebesar $66,67 \%$

Tabel 5. Deskripsi indikator Menginterpretasi hasil sesuai dengan permasalahan awal

\begin{tabular}{cc}
\hline Kode Siswa & Jumlah Skor \\
\hline 001 & 1 \\
002 & 2 \\
003 & 2 \\
004 & 2 \\
005 & 1 \\
006 & 3 \\
Jumlah & 11 \\
\hline Persentase (\%) & $45,8 \%$ \\
\hline
\end{tabular}

Berdasarkan tabel 5 tersebut menunjukan kemampuan Menginterpretasi hasil sesuai dengan permasalahan awal diperoleh persentase sebesar $45,8 \%$.

Tabel 6. Deskripsi indikator Membuat model matematik dari suatu situasi atau masalah sehari-hari

\begin{tabular}{cc}
\hline Kode Siswa & Jumlah Skor \\
\hline 001 & 1 \\
002 & 2 \\
003 & 1 \\
004 & 1 \\
005 & 1 \\
006 & 2 \\
Jumlah & 8 \\
\hline Persentase (\%) & $33,33 \%$ \\
\hline
\end{tabular}

Berdasarkan tabel 6 tersebut menunjukkan bahwa kemampuan membuat model matematik dari suatu situasi atau masalah sehari-hari diperoleh persentase sebesar 33,33\%.

\section{Pembahasan}

Dari penilitian yang telah dilakukan diatas bahwa kemampuan pemecahan masalah melalui model mamatika di atas baik.

Melihat rata-rata presentase dari semua indikator,maka hasil perhitungan persentase pencapaian kemampuan pemecahan masalah matematis dapat dilihat pada tabel 7 di bawah ini:

\begin{tabular}{lcc}
\hline \multicolumn{1}{c}{ Indikator } & Persentase & Kriteria \\
\hline $\begin{array}{l}\text { Mengidentifikasi unsur yang diketahui, ditanyakan } \\
\text { dan kecukupan unsur }\end{array}$ & $87,5 \%$ & Sangat Tinggi \\
$\begin{array}{l}\text { Memilih dan menerapkan strategi untuk } \\
\text { menyelesaikan masalah matematika }\end{array}$ & $58,33 \%$ & Sedang \\
$\begin{array}{l}\text { Menggunakan matematika secara bermakna } \\
\text { Menginterpretasi hasil sesuai dengan permasalahan }\end{array}$ & $66,67 \%$ & Tinggi \\
$\begin{array}{l}\text { awal } \\
\begin{array}{l}\text { Membuat model matematika dari suatu situasi atau } \\
\text { masalah sehari-hari }\end{array}\end{array}$ & $33,8 \%$ & Sedang \\
\hline
\end{tabular}


Berdasarkan hasil perhitungan persentase dari kelima indikator dapat dilihat bahwa indikator membuat model matematik dari suatu situasi atau masalah sehari-hari memperoleh persentase paling rendah. Hal ini sejalan dengan hasil penelitian Khasanah(2015)yang mengatakan dalam menyelesaikan soal kemampuan pemecahan masalah siswa masih mengalami kesulitan dalam mentransformasikan kalimat kedalam model matematika. Lebih lanjut Paridjo (Kartikasari, R, 2017)kesulitan siswa dalam menyelesaikan soal cerita adalah kesulitan siswa memahami cerita itu, menetapkan besaran-besaran yang ada serta hubungannya sehingga diperoleh model matematika dan meyelesaikan model matematika tersebut secara matematika.

\section{Soal no 1}

Disebuah desa terdapat sebidang tanah yang berbentuk persegi dengan panjang sisinya $10 \mathrm{~m}$. Pak Raden berniat membuat pertambakan ikan mas ditanah tersebut dengan ukuran panjang 8 $\mathrm{m}$ dan lebar $4 \mathrm{~m}$. Sekeliling pertambakan ikan Pak Raden akan ditanami rumput. Pak Raden ingin mengetahui luas tanah yang ditanami rumput.

a. Cukupkah data yang sudah ada untuk menentukan luas tanah yang ditanami rumput?

b. Bagaimana cara untuk menentukan luas tanah yang ditanami rumput ?

Jawaban:

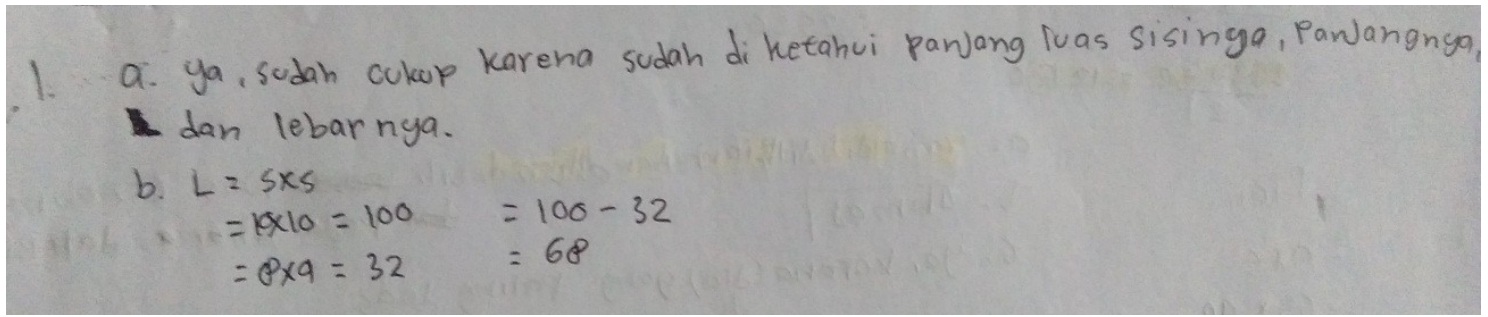

Gambar 1

Dari jawaban siswa pada gambar 1dia menjawab hampir benar namun saja tidak mencantumkan satuan ukurnnya . Pada indikator soalmengidentifikasiunsur yang diketahui, ditanyakan dan kecukupan unsurini rata-rata presentase siswa mencapai 87,5\%, hal ini menandakan bahwa sebagian besar siswa mampu menjawab pertanyaan dengan benar dan kemampuan siswa tergolong cukup tinggi. Berdasarkan hasil wawancara mereka mengetahui sauna ukuran panjang hanya saja mereka kurang teliti dan terburu-buru saat mengerjakannya.

\section{Soal no 2}

Shizuka mempunyai sebuah taman bunga seperti pada gambar dibawah. Taman bunga tersebut ditanami bunga aster kuning dan bunga mawar merah. Shizuka ingin mengetahui berapakah perbandingan taman yang ditanami aster kuning dan mawar merah.

a. Bantulah Shizuka untuk mengetahui perbandingan taman yang ditanami aster kuning dan mawar merah, bagaimana caranya?

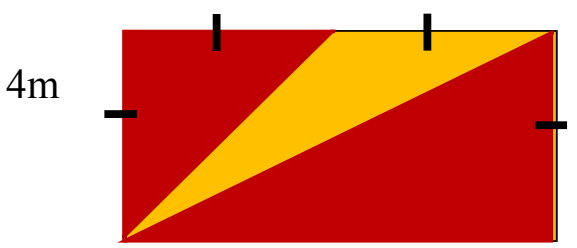


Jawaban:

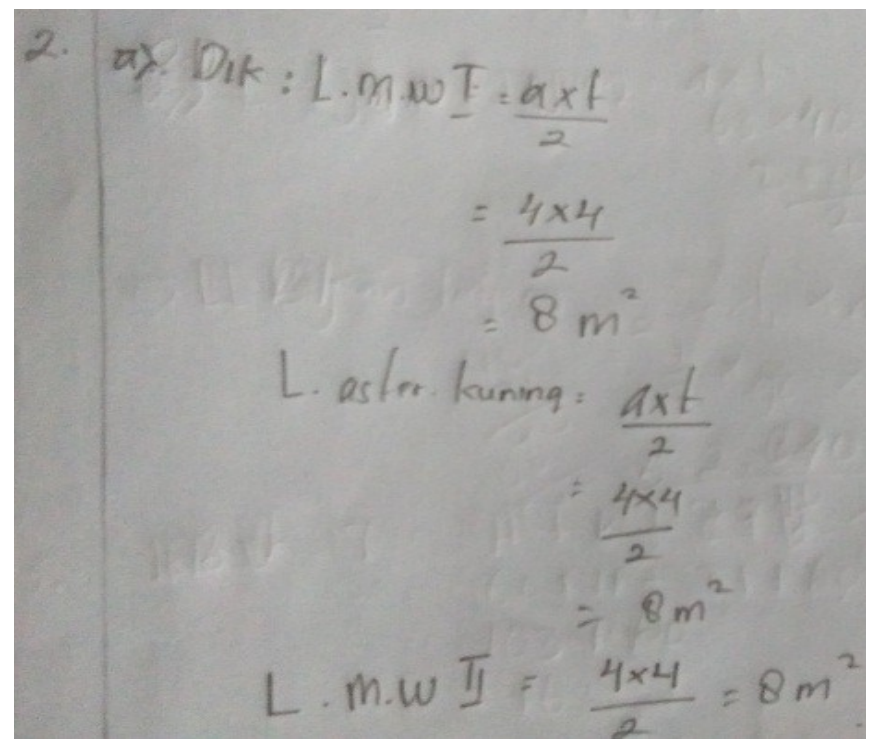

Gambar 2

Jawaban siswa pada soal nomor 2 sebagian siswa belum dapat memahami soal dengan benar. Karena yang diminta pada soal yaitu perbandingan antara aster kuning dan mawar merah namun mereka hanya mengalikan saja angka yang tertera tanpa memikirkan strategi. Pada indikator soalmemilih dan menerapkan strategi untuk menyelesaikan masalah matematika persentase sebesar 58,33\%. Berdasarkan hasil wawancara dengan siswa tersebut dia menjelaskan bahwa siswa kebingungan karena hanya ada 1 angka saja yang dicantumkan, hal ini menunjukkan bahwa siswa belum dapat berpikir tingkat tinggi.

\section{Soal 3}

Ikhsan akan membuat layang-layang. Kerangka layang-layang dibuat dengan diagonal $21 \mathrm{~cm}$ dan $40 \mathrm{~cm}$, kemudian kerangka layang-layang tersebut akan dilapisi kertas. Ikhsan menyediakan kertas berukuran $63 \mathrm{~cm}$ x 80cm dengan harga kertas Rp. 30.000,00.

a. Dapatkah kamu mengetahui berapa layang-layang yang dapat dibuat Ikhsan? Bagaimana caranya?

b. Jika kamu sudah mengetahui banyaknya layang-layang yang dapat dbuat Ikhsan, kemudian dapatkah kamu menentukan berapa harga kertas untuk tiap layang-layang? Jawaban: Dan apa yang dapat kamu simpulkan? 


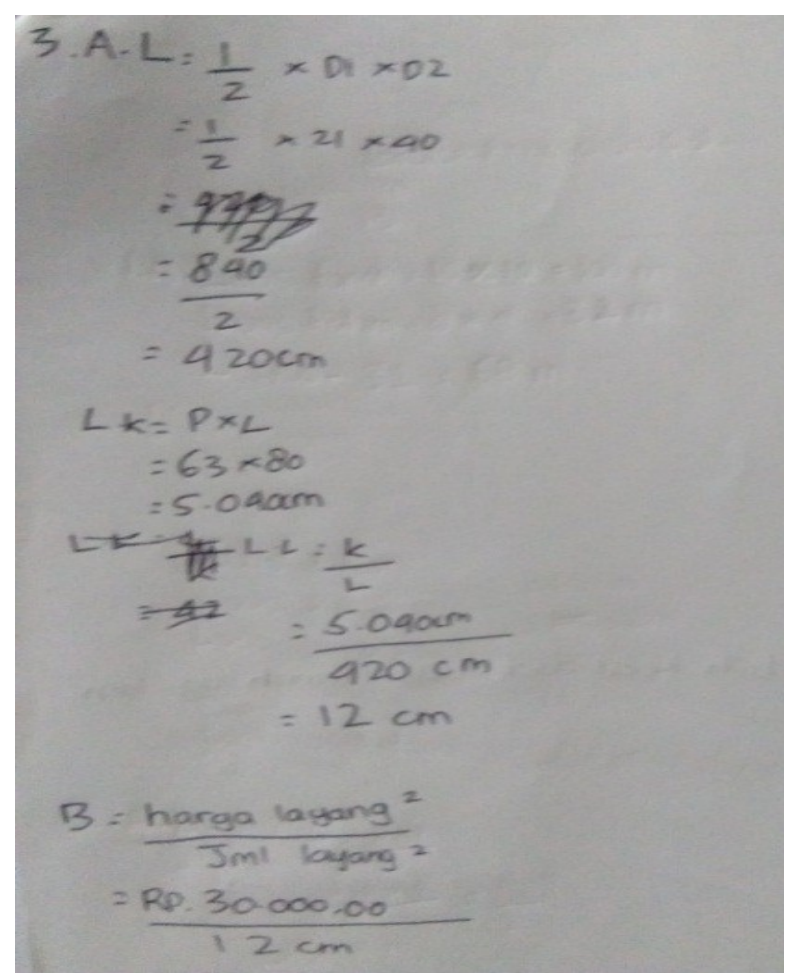

\section{Gambar 3}

Jawaban siswa pada gambar 3 menunjukan siswa sudah mampu mengerjakan soal tersebut namun saja pada pertanyaan bagian b yang seharusnya jumlah layang-layang, siswa tersebut mengisi dengan menggunakan satuan ukuran panjang. Pada indikator soal menggunakan matematika secara bermakna ini siswa mampu menjawab dengan rata-rata presentase sebesar $66,67 \%$ hal ini menyatakan bahwa kemampuan siswa pada menjawab soal indikator inisudah cukup baik. Berdasrakan hasil wawancara dengan siswa tersebut dia menjelaskan bahwa dia kurang fokus dalam mengerjakan soal.

\section{Soal 4}

Pak Rizal berencana membagikan tanah kepada ketiga anaknya yaitu Akbar, Ahmad dan Rian dengan denahnya sebagai berikut:

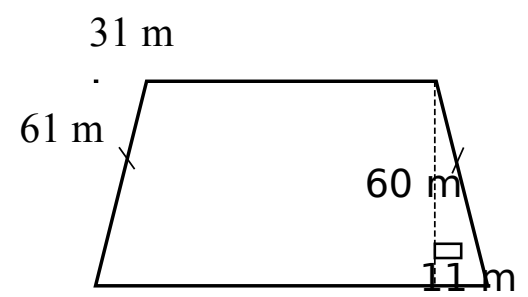

$63 \mathrm{~m}$

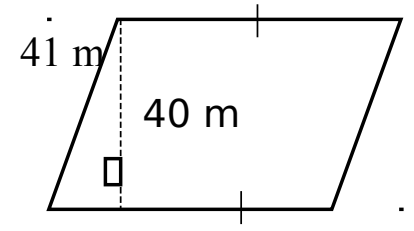

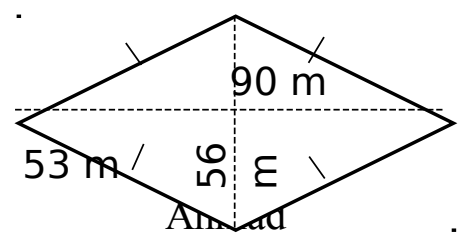


Surat tanah akan dibagi jika ketiga anaknya sudah memagari tanah bagiannya dengan biaya masing-masing. Ternyata Akbar yang paling diuntungkan. Biaya memagari sekeliling tanah permeternya adalah Rp. 4.500,00.

a. Adilkah pembagian tanah tersebut? Bagian siapakah yang paling luas tanahnya?

b. Siapakah yang memagari tanahnya dengan biaya yang paling besar?

c. Benarkah Akbar yang paling diuntungkan? Jelaskan alasanmu.

Jawaban :

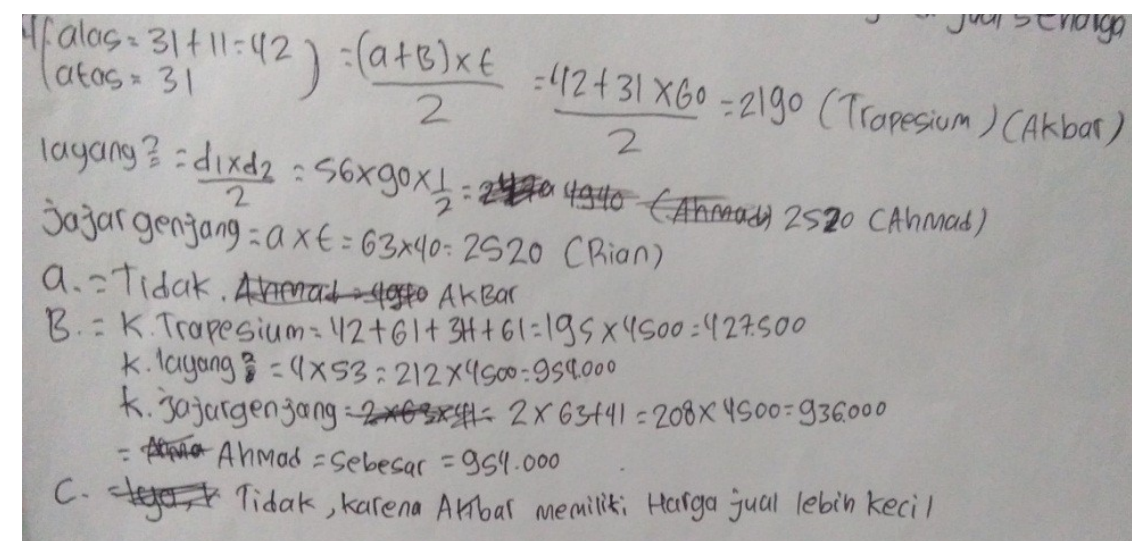

Gambar 4

Jawaban siswa dari gambar 4 siswa dapat mengerjakan soal dengan selesai namun isi yang diperoleh tersebut salah. Dia salah dalam menghitung tanah yang berbentuk trapesium. Pada indikator soal menginterpretasi sesuai dengan permasalahan awal ini siswa mampu menjawab dengan rata-rata presentase sebesar $45,8 \%$, hal ini menandakan kemampuan siswa pada menjawab soal indikator ini rendah. Berdasarkan hasil wawancara dengan siswa tersebut menjelaskan bahwa dia keliru dalam menghitung luas dan keliling trapesium. Karena dia bingung panjang alas trapesium tersebut.

\section{Soal 5}

Pak Tino mempunyai kebun jeruk berbentuk persegi dan Pak Abdul mempunyai kebun durian berbentuk persegi panjang. Ukuran kebun durian Pak Abdul $20 \mathrm{~m}$ lebih panjang dari sisi kebun Pak Tino, sedangkan lebarnya $10 \mathrm{~m}$ kurang dari panjang sisi kebun jeruk Pak Tino. Jika diketahui kedua luas Pak Tino dan Pak Abdul sama, maka menurut kamu berapa Luas kebun Jeruk Pak Tino?

Jawaban:

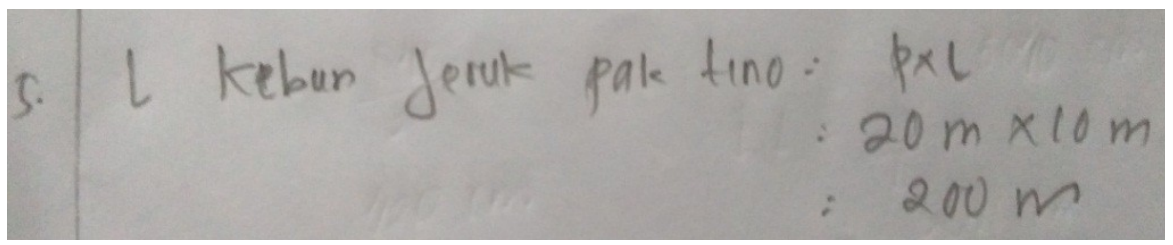

Gambar 5

Jawaban siswa dari gambar 5 menunjukkan bahwa siswa kebingungan dalam mengerjakan soal tersebut, karena yang diminta itu adalah berapa luas kebun jeruk pak Tino dengan melalui proses pemodelan matematika. Tetapi yang siswa kerjakan hanya mengalikan angka yang tertera pada soal saja. Pada indikator soal membuat model matematik dari suatu situasi atau masalah sehari-hari siswa mampu menjawab dengan rata-rata persentase 33,33\%, hal ini menunjukkan bahwa kemampuan siswa tersebut masih sangat rendah. Berdasakan wawancara dengan siswa tersebut menjelaskan bahwa siswa merasa bingung harus bagaimana 
awal dia mengerjakannya, siswa tidak mengerti karena belum pernah menemui soal seperti ini sebelumnya.

\section{KESIMPULAN}

Berdasarkan penelitian kemampuan pemecahan masalah matematis siswa SMP di Desa NgamprahKabupaten Bandung Barat pada materi segiempat dan segitiga masih rendah. Adapun presentasenya sebagai berikut untuk indikatormengidentifikasiunsur yang diketahui, ditanyakan dan kecukupan unsurmerupakan yang tertinggi yaitu 87,5\% menandakan sebagian siswa mampu mengidentifikasi unsur yang diketahui, ditanyakan dalam soal tersebut, indikatormemilih dan menerapkan strategi untuk menyelesaikan masalah matematika sebesar $58,33 \%$, indikator menggunakan matematika secara bermakna sebesar66,67\% dan pada indikator menginterpretasisesuai dengan permasalahan awal sebesar 45,8\% dan yang terendah ada pada indikator membuat model matemaik dari suatu situasi atau masalah sehari-hari sebesar 33,33\%. Pada soal indikator tersebut siswa tidak mampu memberikan jawaban apa yang diingikan, hal ini disebabkan karna siswa tidak dapat membuat model matematik dan siswa belum pernah memperoleh soal seperti soal tersebut.

\section{DAFTAR PUSTAKA}

Apriyani. (2010). Penerapan Model Learning Cycle "5e" dalam Upaya Meningkatkan Kemampuan Pemecahan Masalah Matematis Siswa SMPN 2 Sanden VIII pada Pokok Bahasan Prisma dan Limas. Jurnal Skripsi UNY.

Hendriana, H., Rohaeti, E, E., Sumarmo, U. (2017). Hard Skill dan Sof Skills Matematik Siswa. Bandung: PT Refika Aditama.

Hendriana, H., Sumarmo, U. (2014). Penilaian Pembelajaran Matematika. Bandung: PT Refika Aditama.

Hidayat,W., Sariningsih, R. (2018). Kemampuan Pemecahan Masalah Matematis dan Adversity Quotient Siswa SMP Melalui Pemebelajaran Open Ended. Jurnal JNPM.

Kartikasari, R. (2017). Analisis Kesulitan Dalam Menyelesaikan Soal Cerita Matematika Pada Siswa SMP. Universitas Muhammadiyah Surakarta.

Kesumawati. (2009). Peningkatan Kemampuan Pemecahan Masalah Matematis Siswa SMP Melalui Pendekatan Pendidikan Matematika Realistik. Prosiding.

Khasanah, U. (2015). Kesulitan Menyelesaikan Soal Matematika. Universitas Muhammadiyah Surakarta.

Muhsin, Johar, R., Nurlaelah, E. (2013). Peningkatan Kemampuan Pemahaman dan Pemecahan Masalah Matematis Melalui Pembelajaran dengan Pendekatan Kontekstual. Jurnal Peluang.

National Council of Teacher Mathematics. (2000). Principle and Standards for School Mathematic. USA NCTM.

Putra, D, H., Thahiram, N, F., Ganiati, M., Nuryana, D. (2018). Kemampuan Pemecahan Masalah Matematis Siswa SMP Pada Materi Bangun Ruang. Jurnal JIPM . 
12 Aisyah, Khasanah, Yuliani, \& Rohaeti, Analisis Kemampuan Pemecahan Masalah...

Ruseffendi, E, T. (2006). Pengantar Kepada Guru Mengembangkan Kompetensinya Dalam Pengajaran Matematika Untuk Meningkatkan CBSA. Bandung: Tarsito.

Suherman. (2003). Evaluasi Pembelajaran Matematika. Bandung: JICA UPI.

Syah, Muhibbin. (1999). Psikologi Belajar. Jakarta: PT. Raja Grafindo Persada. 